\title{
The Role of Soft Skills in Preventing Educated Unemployment: A Phenomenological Approach of University Graduatesin Jakarta
}

\author{
Widiyono, SE, MM \\ STIAMI - Institute of Social Sciences and Management \\ Jl. Pangkalan Asem Raya No. 55 Cempaka Putih \\ Jakarta-Indonesia
}

\begin{abstract}
This study aims to find out how universities equip students with soft skills to be graduates who are ready to enter into the society and how the student's perspective on soft skills. The interviewswere taken place in 5 universities in Jakarta. This study uses qualitative method with phenomenological approach. Primary data were obtained from direct data sources by interviewing informants consist of students, lecturers, educational practitioners as well asthe government institution at the policy level. Secondary data obtained from the results of previous review or research review. The results of this study indicate that up to the present time the soft skills in universities in Jakarta have not been implemented well so that there are still a lot ofuniversity graduates get difficulties in entering into the working world or starting a new business. This implies on the increase in number of educated unemployment.
\end{abstract}

Keywords: soft skills, educated unemployment, university graduates

\section{Introduction}

Higher education has an important role for a nation to improve the quality of human resources and the progress of the nation itself. Higher education can provide greater opportunities for graduates to get the best job, because prospective workers who have a background from a college will be more trusted as people who have more practical skills. However, not all college graduates have more abilities than people who do not take tertiary education. It depends on the students themselves. There are many types of students in a college, such as students who are not really active in organization, there are also students who really want to learn and develop their abilities, and there are other students who are busier with activities outside the campus so the teaching and learning process is neglected. Many graduatesof public universities who hold bachelor's degrees every yeardo not reduce unemployment by providingworkfields in the community in accordance with their expertise, but making the unemployment curve in Indonesia higher. The Central Bureau of Statistics (BPS) in 2013 revealed that there were 422.000 Indonesian scholars who were unemployed. From this number, it means that 5,5\% of the total unemployment in Indonesia wereuniversity graduates. In 2017, there had been an increase in the number of unemployed people in Indonesia by 10,000 people to 7.04 million people in August 2017 (BPS, 2017). The increase in unemployment is caused by an increase in the number of workforce in Indonesia. The majority of graduates have good grades (cumlaude), but intellectualization or quality of students is low, so that when the graduates start applying for a job or building their own business, they face a lot of problems which are actually caused not from the hard skills but soft skills. Problems in communication skills, ethics, self confidence, lack of motivation, and other aspects related to soft skills become the main factors of educated unemployment.

In the world of work it is believed that superior human resources are human resources who do not only have hard skills but also have the ability in the aspects of soft skills. A lot of companies choose employees based on their personality and not the GPA (Faizal, 2012) with the reason thattraining the technical skills is much easier than forming the character. Soft skills can be sharpened along with an increase of one's experience. Meanwhile, from the side of job seekers, good soft skills will support a person to be accepted by companies. However, up to the present time, there are still a lot of universities in Jakarta haven't delivered the soft skills effectively.

Based on the above problems, this paper aims to find out how universities providesoft skills for the students to be graduates who are ready to enter into the society and the students' perspectives on the importance of soft skills competence for university students.

\section{Literature Review}

\subsection{Educated Unemployment}


According to the ILO guidelines, a person is unemployed if the person is (a) not working, (b) currently available for work and (c) seeking work. Practical implementation of theseguidelines is, however, generally difficult. While employed persons are relatively easilyclassified in most countries, the issue of classifying non-employed persons as eitherunemployed or out of the labor force, especially according to criteria (c) is notuncontroversial; see, for instance, OECD (1995).

The phenomenon of educated unemployment in developing countries contrasts with the pattern of unemployment in developed countries. In the latter, the unemployment rate and educational attainment are strongly negatively correlated (Ashenfelter and Ham, 1979). The causes of "educated unemployment" in developing countries have attracted relatively little attention in the development economics literature.

Given the lack of sufficient employment opportunities in the formal sector, young people may be forced to engage in casual work and other unorthodox livelihood sources, thus leading to underemployment (Echebiri, 2005; Onah, 2011).According to Fajana (2000), unemployment refers to a situation where people who are willing and capable of working are unable to find suitable paid employment. It is one of the macro-economic problems which every responsible government is expected to monitor and regulate. The higher would be the poverty level and associated welfare challenges. Fajana (2000), Alao (2005), and Wikipedia (2010) identify the following types of unemployment: (1). Frictional Unemployment is caused by industrial friction in which jobs may exist, yet the workers may be unable to fill them either because they do not possess the necessary skill, or because they are not aware of the existence of such jobs. The employable may remain unemployed on account of shortage of raw materials, or mechanical defects in the working of plants. Therefore, the better the economy is doing, the lower this type of unemployment is likely to occur; (2). Residual Unemployment is caused by personal factors such as old age, physical or mental disability, poor work attitude and inadequately training; (3). Technological unemployment is caused by changes in the techniques of production. Technological changes are taking place constantly, leading to the increased mechanization of the production process. This naturally results in the displacement of labor and finally causing unemployment.

\subsection{Soft Skills}

There are a lot of experts definethe soft skills. Flex Day (2012) stated "that students need soft skills for their success in careers and the workforce.Therefore soft skills need to be taught to students in colleges.According to Grisi (2014) hard skills allow man to be what he is: an engineer, a physicist, a philosopher. Soft Skills operate in a direction that is rather separate from the role of the individual and go beyond the strict demands of the profession. Soft Skills can be furthermore distinguished in Entrepreneurship Skills and Technological Skills. Entrepreneurship Skills are connected to leadership, to risk facing, to innovation and change management and correspond to Soft Skills.The parallel with Software and Hardware in Information Technology is evident: Software controls and manages Hardware. This is particularly true in the Indo-European approach, while in the Oriental one there is more integration between the two parts (Ciappei, 2015).

Malcolm Gladwell (2011) states that people who have better soft skills are able to take the jobs and solve their problems at life in comparison to the people who have less soft skills. The soft skills are skills people use to communicate, solve problems, lead, empathize, and think creatively (Wentz, 2012). Whereas, Elfindri (2011) says that soft skills are skills and life skills, both for themselves, in groups, or in community, and with the creator. Soft skills make someone skilled at communicating, controlling emotions, and mastering foreign languages. In this light, in a knowledge-based economy one advocates that competence involves a combination of knowledge, skills and attitudes and that education should promote diversified skills, which is contrary to the traditional knowledge-based model. In this context, cultural competence outshines as a determining factor of personal and professional success (Chen, 2016). The perspective defended by Hawkins and Winter (1996) is supported by Stagg (1996, p. 11) who says an academic curriculum should be broad, comprehensive and balanced in order to "prepare pupils for the opportunities, responsibilities and experiences of adult life". Therefore, students should be driven and eager to acquire new skills to achieve self-efficacy, and respond to pluralism and social inclusion (Ibáñez-Martín, Fuentes \& Barrio, 2012; Tejada \& Ruiz, 2016). Smidt (2015) does also consider that there is a close relationship between the academic success and professional competence. This is the line of thought in which Thongthew (2014) asserts that the education systems call for changes to better prepare individuals for the expected changes of society. Therefore, the curricula must endow students with diverse skills and critical thinking to adapt to the new technological age because knowledge complexity requires education systems to get involved in soft skills (Martins, Martins \& Pereira, 2013).

Basically, soft skills refer to personalities, attributes, qualities and personal behaviour of individuals. Soft skills include certain abilities such as communication, problem-solving, self-motivation, decision-making, and time management skills (Gupta, 2009). Hodges and Burchell (2003) investigated the perceptions of business employers of the importance of different skills. 
It was reported that eight out of top ten skills were soft skills which included the ability and willingness to learn, teamwork and cooperation, interpersonal communication, energy and passion, and problem-solving skills. John W. Santrock (2007, p. 121), said that "character education is a direct approach to moral education by giving lessons to students about basic moral knowledge to prevent them from doing immoral behavior or endangering themselves or others". Thomas Lickona offers another definition, "character education is an effort that is done deliberately to help someone so that he can understand, pay attention to and carry out basic ethical values" (Lickona, 1991: 51).A study covering over 52 different professions with more than 8,000 managers in the United States identified soft skills of employees as the major competency in nearly all the professions, even in the technical environments (Rubin, 2009).Consequently, there is now more pressure on academic institutions to enhance soft skills of their students.

Soft skills are intrapersonal and interpersonal attributes of personality that can differentiate a person from others in their community and differentiate people from levels or levels of work or careers in one job (Utama et al, 2009: 3). Interpersonal intelligence is the ability to understand and be sensitive to the Central Bureau of Statistics (BPS), revealing, in 2017 the principles, intentions, motivations, temperaments, temperament of others, sensitivity to facial expressions, voices and gestures of others (cues), as well as the ability to establish relationships and communication with other people. While intrapersonal intelligence is the ability to understand themselves and act adaptively based on knowledge of high self-awareness, initiative and courage (Gardner, 1993).

Furthermore, Lystiani (2011) defines soft skills as skills in analytical thinking that build, think logically, critically, are able to communicate and cooperate in teams, and behave in the work so that they can be independent. Soft skills are non-academic competencies that become a person's capital in order to achieve success in a career and be more successful and function in community life. Jordan et al. in Widhiarso (2002) found that individuals who have low emotional intelligence appear to be less performing when working in a team. This can be seen from the inability to adapt, read social situations and manage tension in the team. In addition to interpersonal relationships, emotional intelligence is generally the dominant predictor of several psychological variables related to success in working or building relationships. Sailah (2008) states that there are ten attributes of soft skills that play a role in the world of work, namely initiative, integrity, critical thinking, willingness to learn, commitment, motivation to achieve achievement, enthusiasm, ability to communicate, reliable and creative.

Soft skills education can also be done through extracurricular activities such as activities carried out in student organizations. In curricular activities, educators should provide soft skills education content in the learning process. Constraints faced in the development of soft skills is that not all educators are able to understand and apply soft skills, many educators do not know the characteristics of soft skills that have been owned by students and the absence of standard procedures in evaluating the success rate of soft skills education that has been given. (Surjoseputro,2014). In various references a lot of definitions of soft skills are found. According to LaFrance (2016: 4), for example, soft skills are defined as "personal and interpersonal behaviors that develop and maximize human performance related to selfconfidence, flexibility, honesty and self-integrity. In line with the definition above, Elfindri (2011: 67), defines soft skills as "skills and life skills, both for oneself, group, or community, and with the Creator". Furthermore, Illah Sailah (2008: 19) argues that soft skills are "a person's skills in dealing with others (inter-personal skills) and self-managing skills (intra-personal skills) that are able to develop the work performance optimally.

Figure 1.Types of Soft Skills

\begin{tabular}{|l|l|}
\hline Types of Soft Skills & Forms of Soft Skills \\
\hline Intrapersonal Skills & Commitment \\
& Leadership skills \\
& Self motivation \\
& Positive work attitude \\
& Creative problem solving \\
& Strategic thinking skills \\
& Willingness to learn \\
& Time management \\
\hline Interpersonal Skills & Communication skills \\
& Persuassion skills \\
& Negotiation skills \\
& Team Work \\
& Conflict Management \\
\hline Combination of Intrapersonal dan & Commitment \\
& Leadership \\
& Honesty \\
& Responsibility \\
& Adaptability \\
& Tolerance \\
& Problem Solving Skils \\
& Decision Making skills \\
\hline
\end{tabular}

Source: Compiled by author from different sources 
The meaning of Intra-Personal and Inter-Personal Competences is well described in Figure 2 based on a research of Daniel Goleman. Any individual is responsible of his actions, these bases on different elements, each of them connected to the others. Awareness and Action interact with Personal and Interpersonal competences, as the figure clearly shows (Kingsley, 2015).

Figure 2 Definitions of Soft Skills by Bryce Kingsley (2015)

Achiever's Orientation

Response Able

Awareness

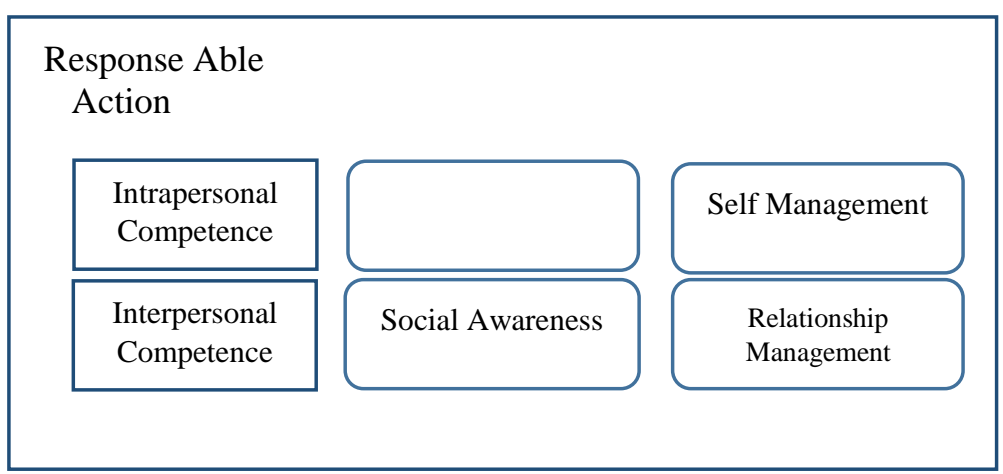

Source: Bryce Kingsley (2015)

\section{Research Method}

In this study, a phenomenological approach was adopted. Phenomenology is an approach to qualitative research that focuses on the similarities of life experiences in certain groups. The fundamental purpose of this approach is to arrive at a description of the nature of certain phenomena (Creswell, 2013). With roots in philosophy, psychology and education, phenomenology attempts to extract the purest, uncontaminated data and in several interpretations of approaches. Bracketing is used by researchers to document personal experience with the subject to help eliminate itself from the process. One of the bracketing methods is making memos (Maxwell, 2013). A phenomenological study explains the meaning for some individuals of their life experiences from concepts or phenomena. Phenomenologists focus on describing the similarities that all participants have when they experience phenomena (eg universally experienced sadness). The basic aim ofphenomenology is to reduce individual experience with a phenomenon for the description of universal essence "to understand the nature of the object," (van Manen, 1990, p. 177). According to Jasper (1994: 309), phenomenology considers that "the true meaning of phenomena is explored through their experiences as explained by individuals". While according to Omery (1983: 49) phenomenology is a descriptive inductive research method whose function is to examine and describe all phenomena including human experience on the road.Phenomenology is an appropriate approach to examine human experience (Wimpenny \& Gass 2000: 1486) and try to uncover hidden meanings in phenomena embedded in narrative words (Sorrell \& Redmond, 1995 cited in Maggs-Rapport 2000: 221). As a research method, phenomenology is a careful, critical, systematic investigation of phenomena (Streubert \& Carpenter 1999: 48). This advantage makes this approach in accordance with our research.

The subjects in this study were selected based on purposive sampling where the technique of determining the informants used certain criteria (Sugiyono, 2006), namely the informants who were parts of the pilot group studied. The data in this study consisted of primary data and secondary data. Data was collected through in-depth interview techniques and documentation (Spradley, 1997; Salim, 2006; Kriyantono, 2008).

Primary data was obtained from direct data sources by interviewing informants, which consisted of 10 fresh graduates from different universities to explore their perspectives on soft skills and how soft skills were applied on the campuses where they had previously studied. Interview was also conducted with 5 rectors to find out how the universities implement the soft skills. Interviews with 3 HRD Managers from multinational companies were intended to find out more about how multinational companies recruit new employees and what aspects are assessed.

Another interview witha policy level official from the Ministry of Research, Technology and Higher Education was taken to explore information related to national policies.

Secondary data is obtained from the results of a review or review of previous research. After the research data is collected, the authors carry out reduction steps, display data, verification and conclusions (Sugiyono, 2006; Salim, 2006). Reduction is done by classifying interview and observation data into themes in accordance with the research objectives. Then the data presented is in accordance with the presentation of qualitative data through narratives. After that, the data is then confirmed to see the validity before conclusions are made. Researchers also use literature studies 
conducted by collecting materials from various books and related references. Literature study is carried out by tracing data about the desired information through online media and through references to sources related to this topic.

\section{Research Findings and Discussion}

From the interview results obtained data that related to the gap between the ideal and the real in the context of character learning in universities, the Government of Indonesia has launched three strategies for developing higher education in Indonesia. The three strategies are Nation Competitiveness, Autonomy, and Organization Health. (Directorate General of Higher Education, 2004: 5-6). Government strategic actions are related to nation competitiveness, namely the development of human resources, especially the quality of university graduates and this is one of the strategies that is very relevant to shorten the gaps between the ideal and the real in the context of character learning in universities in Indonesia today. Characterbuilding must be done to improve thinking skills, learning skills and living skills. Learning Skills are skills that are used so that students can always develop themselves through a continuous learning process. Thinking skills are skills needed when students think about solving problems in everyday life and living skills are the skills needed to adapt to everyday life.

Interviews with fresh graduates and lecturers from private universities show that the soft skills provided by universities in Jakarta vary widely in different ways, as follows:

\section{Soft Skills in the orientation of new students}

On average, universities in Jakarta provide opportunities for new students to attend matriculation programs or study orientation and introduction to campus. This program takes place in a variety of time ranges from 2 days to 2 weeks. In general, universities that only give matriculation time for 2 days are no more just a welcoming ceremony for students and an introduction to campus management. But the rest is only filled with activities such as general direction and activities with senior students. Not all universities have given such matriculations. There are universities that provide opportunities for new students to get to know their campus more closely but the activities are mostly left to senior students so that there is no subject whatsoever is obtained, because the lecturers do not intervene. However there are also universities that provide matriculation programs for 1 to 2 weeks which include enrichment of English, Communication, Leadership, Motivation, Communication between Cultures and materials which are elements of character and moral development.

"The first time I joined university, I attended the character building activities. It was actually a good pre-lecture programme but unfortunately the time allocation was very limited. It was only 2 weeks and the subjects delivered were quite many such as how to build self confidence, creative thinking, critical thinking, public speaking etcetra. As a result, the goalto improve students' soft skills was not really achieved, and new problems come when they graduate from universities."

In general, universities that carry out matriculation with such debriefing are only limited to state universities and private universities that are quite reputable, considering that to carry out this program, it is also necessary to pay fees outside of tuition fees.

\section{Soft skills through the learning process on campus}

The interviews with leaders of universities show that in addition to campus orientation, soft skills are also provided by universities through the learning process. Since the issuance of the Minister of National Education Decree 045/U /2002, the learning process in universities in Indonesia must change, from the teacher centered system to student centered learning. So, this is not merely to replace the list of courses, or the composition of the course, but more essential is the change in the learning process, delivery and evaluation. Education that focuses only on content must shift to the process. At present, learning ownership is no longer centered on lecturers but rather students who are actively constructing science, so the emphasis is not only on theory but also on how a work is done. Therefore, changes in the curriculum are important, from content-based curricula to competency-based curriculum (CBC). If the attribute of soft skills to be developed is oral communication, the learning process that uses group presentations and discussions is necessary. However, if the collaboration will be focused, then group assignments need to be done. Thus students are also trained to solve problems, communicate with all group members and are able to think creatively.

"The main problem that we face up to the present time concerning the CBC is the lecturers' commitment. They are a lot of lecturers who are competent in the subjects they teach but do not really have a commitment to apply the CBC. Most of them still focus on traditional teaching method which is teacher-centered. So, it is another challenge that we have to overcome now. However, if the CBC can be applied well by lecturers, I am sure that it can help improve the quality of university students and prevent them from unemployment." 
The above answer confirms the statement of Surjoseputro (2014) that says that constraints faced in the development of soft skills is that not all educators are able to understand and apply soft skills, many educators do not know the characteristics of soft skills that have been owned by students.

\section{Soft skills through non-academic activities}

In general, universities have student activity units managed by the student senate. This type of non-academic activity is very varied such as art, religious activities, nature lovers, sports, linguistics, including international student exchange programs or activities to volunteer abroad. Every student is required to participate in at least one non-academic activity. All of this is intended to improve students' soft skills. By taking part in organization, students learn to work together regardless of which tribes and religions they belong to so that they are more tolerant, able to build the spirit of leadership, learn to express their opinions, and able to think creatively. Even if there are students who take part in youth exchange, it is expected that he can improve the competence of intercultural communication, so that he can become a person who has excellent interpersonal communication and intrapersonal communication. At present, most of universities havea requirement that before taking the thesis defence, students must submitthe certificates or awards obtained from seminars, workshops, youth exchanges or non-academic activities. The number of certificate varies from one university to another. Some require 20 certificates, but some require only 5 certificates. When the researchers interviewed 10 fresh graduates, all of them said that the non academic activities were useful for them. Inspite of increasing their knowledge and skills, they also can improve their soft skills. However, in the implementation, not all of the students take courses related to soft skills as suggested by the universities. They prefer taking the courses which are related to hard skills in accordance with their major in comparison with the soft skills such as communication, etiquette and personality, public speaking, leadership etc.

"It is good that students will have the opportunities to improve their soft skills by following seminars, workshops or training. However, students prefer taking the workshops which are related to their major only and not taking the courses on soft skills. So, when they graduate, they still do not have adequate skills of communication, critical and creative thinking skills, lack of motivation, they don't have initiative, unable to work in teams and most of them still can't behave professionally.I think universities have to give clear requirements for all students what types of soft skills related courses they have to take so that universities can create quality graduates that will be successful to work as employees or entrepreneurs."

This is in line with Sailah's statement (2009) that there are ten attributes of soft skills that play a role in the world of work, namely initiative, integrity, critical thinking, willingness to learn, commitment, motivation for achievement, enthusiasm, ability to communicate, reliable and creative. In addition, fresh graduates are generally unable to cooperate in teams and have not been able to behave professionally and have no independence as stated by Lystiani (2011).

The interviews with Human Resources managers of multinational companies show that on average, fresh graduates from private universities do not have adequate soft skills. The average fresh graduatesare still lacking in terms of communication skills. Communication here hasa broad meaning that includes interpersonal communication and intrapersonal communication. In interpersonal communication, they seem rigid in building good relationships with coworkers and with clients. Their leadership spirit is still not visible except those who have organizational experience when on campus. Fresh graduates are also lack sensitivity so that they are often considered to be less respectful to others. While intrapersonal ability is mainly seen from their lack of having creative thinking skills, initiative and planning as well as low self-confidence. When given more than usual tasks, it looks easy to stress. "We will be surprised to see their academic transcript since they have a Grade Point Average (GPA) above 3.7 and almost 4." This shows that the real condition of students in the learning process in higher education focuses more on the touch of cognitive aspects and less attention on students' soft skills. Reality shows that GPA can only describe a person's quality in the cognitive aspect and has not been able to show someone's qualifications in the field of soft skills or also called social skills. Based on the results of a survey by the National Association of Colleges and Employers, USA, 2002 it turned out that the GPA was not something that was considered important in the world of work. Adaptability and other interpersonal competencies, with a value orientation uphold effective performance. At this time there is a big gap in the ability of graduates in hard skills and soft skills. The ratio is still $80 \%$ and $20 \%$. No wonder many fresh graduates who, after going through a probationary period for approximately three months, have not been able to occupy the position of leader or manager.

Therefore the company must spend special budget to conduct training for new employees who pass the probational period. However, many of them have to end their probational period by employment termination. When compared to hardskills training, it turns out that soft skills training are much more needed.

There are also many fresh graduates who fail at the time of interview because the quality of a person will look more concrete at the interview, starting from communication skills, foreign language skills, leadership spirit, behavior and 
personality, ability to cooperate, andlack of self confidence. In general, many of them feel that they can easily be accepted to work in a prestigious company because of their high degree and GPA. However, they do not know that to be successful in the interview, they need to show their soft skills more than the hard skills. Such fresh graduates eventually led to be educated unemployment. Soft skills are very prominent in bringing people to survive at the peak of success. Not surprisingly, soft skills and hard skills are always compared to software and hardware where software controls and manages hardware and not vice versa. In other words, what determines their success is not the technical skill, but the quality of self that belongs to the soft skills category or people skills. In Germany it is also known as the term strategic skills or key qualifications. The company knew him with the slogan: "We hire people for their technical skills, but then ... we fire them for behavioral faults."

From the interviews conducted with a policy level official of the Ministry of Research and Technology and Higher Education, it is known that Law Number 20 of 2003 concerning the National Education System, Chapter 1, Article 1, Paragraph 1 states that education is a conscious and planned effort to create alearning atmosphere of learning and learning process so that students actively develop their potential to have spiritual strength (soft skills), self-control (soft skills), personality (soft skills), as well as skills needed by themselves, society, nation and country. So it is clear that there are regulations for each educational institution to provide soft skills to its students. However, this policy does not clearly state the mechanism of implementing the soft skill. So, it is left to each campus.

In addition to supporting the improvement of students' soft skills, the government has also established a Competency Based Curriculum (CBC) system since 2014, with the reasons of :

1. There are various inequalities in life, such as morals, morals, national identity, social and political, and economic.

2. Increasingly limited resources and opportunities to obtain decent work and life at the local, national, and competitive levels at the global level.

3. The development of science and technology and its impact on life.

4. In general, the results of our education have not been satisfactory. This is reflected in the reports of several international institutions regarding the level of competitiveness of our human resources with other countries.

Therefore the CBC is applied. With this new curriculum, the previous lecture methods namely teacher-centered is transformed into student centeredlearning, with the following methods: (1) Small Group Discussion, (2) Role-Play \& Simulation, (3) Case Study, (4) Discovery Learning, (5) Self-Directed Learning, (6) Cooperative Learning, (7) Collaborative Learning, (8) Contextual Instruction, (9) Project Based Learning, and (10) Problem Based Learning and Inquiry.

One method in CBC is Problem Based Learning (PBL) which is a method of approaching education by using problems as a stimulus to help students discuss important issues. PBL is expected to improve students' ability to think critically and be able to identify their own learning needs. This will stimulate students to actively search for the learning resources needed so as to obtain the necessary information and ultimately their knowledge, skills, and attitude will be better.

Some universities have also included Entrepreneurship subject with the aim to change the mindset of students from the aspiration of being employees to become entrepreneurs in order to be independent,not looking for a job but creating the work field. However, again problems occur with the weaknesses in soft skills. Being an employee or businessman at the same time requires superior soft skills, especially to become an entrepreneur. Without high motivation and confidence, someone will easily give up.

The main obstacle in the implementation of the $\mathrm{CBC}$ is the meaning of the $\mathrm{CBC}$ and changes in the structure as a complete unit of implementation of the $\mathrm{CBC}$ which are still not understood by the management of universities, lecturers, and the academic community. There are still many lecturers who teach in conventional ways that lead to teacher centered learning because they only think about cognitive achievement from their students without considering the soft skills aspect. Resource limitations in some universities still require a long time as well as serious efforts to make it happen. Therefore, universities must strengthen their human resources so that programs to increase students' soft skills can run effectively and thus can prevent educated unemployment.

In general, fresh graduates only rely on the academic title they have just held and the GPA which is above average. They think that with the title and GPA they will easily get a job without thinking about the need for other professional competencies. This thought is wrong and not in line with what was said by Smidt (2015) who argued that there is a close relationship between the academic success and professional competence.Fresh graduate currently also has no sensitivity and tolerance and is difficult to adapt to the new environment and work culture. The lack of competence in communication causes these fresh graduates lack of ability to mingle and work together in teams consisting of members from various cultures and religions, so that they are less responsive to social inclusion. 
This confirms the statement ofIbáñez-Martín and Fuentes \& Barrio (2012) and Tejada \& Ruiz (2016) that students should be driven and eager to acquire new skills to achieve self-efficacy, and respond to pluralism and social inclusion.

\section{Conclusion and Recommendation}

Based on the above description, it can be concluded that in general private universities have implemented programs that aim to improve students' soft skills, but the implementation has not been effective and is still constrained by the capabilities of its human resources. This can be seen from the quality of the graduates they produce who still have difficulty in getting a job or starting a business and the main problem is not in the ability of hard skills but in their soft skills. To prevent the increasing number of educated unemployment, universities need to improve the quality of lecturers in terms of delivering the soft skills and thinking about strategies and approaches taken so that the graduates possess the soft skills competencies needed in the global era. For further research, the authors recommend to carry out a research on effective strategies for implementing soft skills programs in universities with differentapproaches.

\section{References}

Affif, Faisal. (2012).Kepemimpinan \& Kewirausahaan Multi Talenta. Bandung: Asean Plant Consult.

Alao, O. (2005). Principles of Economics, Lagos: Darkol Press and Publishers. Awogbenle

Ashenfelter, Orley and Ham, John (1979). Education, Unemployment, and Earnings. Journal of Political Economy, Vol. 87, No. 5, Part 2: Education and Income Distribution (Oct., 1979), p. S99-S116. The University of Chicago Press Stable. URL: http://www.jstor.org/stable/1829910.

Central Bureau of Statistics (BPS).(2013). StatistikIndonesia 2013. Nomor Katalog : 1101001. Nomor Publikasi : 07330.1306. Tanggal Rilis : 2013-05-01.

Central Bureau of Statistics (BPS).(2017). Keadaan Angkatan Kerja di Indonesia. Agustus 2017. Nomor Katalog : 2303004. Nomor Publikasi : 04120.1704. ISSN : 0126-647x. Tanggal Rilis: 2017-11-30.

Chen, P. Y. (2016). Teaching in offshore programmes: an assessment of university faculty's self-efficacy, cultural competence and preparedness. Journal of Education for Teaching, 42(2), 188-204.

Ciappei, C. (2015). Soft Skills to govern action. Speech at "Soft Skills and their role in employability - New perspectives in teaching, assessment and certification", workshop in Bertinoro, FC, Italy. November 2015.

Creswell, J. W. (2013). Qualitative Inquiry \& Research Design Choosing among Five Approaches (3rd ed.). Thousand Oaks, CA SAGE.

Echebiri, R.N. (2005). Characteristics and Determinants of Urban Youth Unemployment in Umuahia, Nigeria: Implications for Rural Development and Alternative Labor Market Variables. Paper presented at the ISSER/Cornell/World Bank conference on "Shared Growth in Africa" held in Accra, Ghana, 21-22 July.

Elfindri (2011).Soft Skill untuk Pendidikan. Jakarta: Baduose Media.

Fajana, S. (2000). Functioning of the Nigerian labour market. Lagos: Labonfin and Company, p. 23.

Day, Flex. (2012). Our Students Need Soft Skills. Mali: Delta College Press.

Gardner, H. (1993).Multiple intelligences: The theory in practice. New York, NY, US: Basic Books.

Gladwell, Malcom. (2011).Outliers :the story of success. New York : Back Bay Books,. MLA.

Grisi, C.G.A. (2014). Soft Skills: a close link between enterprises and ethics. Speech at "Soft Skills and their role in employability - New perspectives in teaching, assessment and certification", workshop in Bertinoro, FC, Italy. November 2014.

Gupta, Y. (2009). Building a better business student. BizEd, 9(6), 62-63.

Hawkins P \& Winter J. (1996). The self-reliant graduate and the SME. Education + Training, 38(4):3-9.

Hodges, D., \& Burchell, N. (2003). Business graduate competencies: Employers' views on importance and performance. Asia-Pacific Journal of Cooperative Education, 4(2), 16-22.

Ibáñez-Martín, J. A., Fuentes, J. L., \& Barrio, J. M. (2012). Competencias sociales e inmigración desde una perspectiva intercultural. Educación XX1, 15(2), 41-72.

Jasper, Melanie. (1994). Issues in phenomenology for researchers. Journal of Advanced

Nursing. Number 19, pages 309-314.

Kingsley, B. (November 2015). Self Awareness and Emotional Intelligence. Speech at "Soft Skills and their role in employability - New perspectives in teaching, assessment and certification", workshop in Bertinoro, FC, Italy.

Kriyantono, Rachmat. (2008). Teknik Praktis Riset Komunikasi. Jakarta : Kencana Prenada Media Group.

LaFrance, Aricia E. (2016). Helping Students Cultivate Soft Skills. http://www.ncda.org/aws/NCDA/pt/sd/news

_article/7010/_PARENT/layout_details_cc/false (retrieved 3 July, 2018).

Lickona, Thomas. (1991). Educating for Character: How our school can teach respect and responsibility. New York, Toronto, London, Sydney, Auckland: Bantam Books.p.51. 
Lystiani, Endang.(2011).Pengembangan Softskill Mahasiswa Calon Guru Melalui Perkuliahan di Jurusan Pendidikan Matematika. Prosiding Seminar Nasional Penelitian, Pendidikan dan Penerapan MIPA, Fakultas MIPA, Universitas Negeri Yogyakarta, 14 Mei 2011.

Martins, A., Martins, I., \& Pereira, O. P. (2013). Organisational flexibility through human capital development. In Knowledge Management Innovations for Interdisciplinary Education: Organizational Applications, Edited by Buckley, S. and Jakovljevic, M., IGI Global, chapter 3: 51-61, DOI: 10.4018/978-1-4666-1969-2.ch003.

Maxwell, J. A. (2013). Qualitative research design: An interactive approach. Thousand Oaks, Calif: SAGE Publications.

Omery, A 1983: Phenomenology: a method for nursing research. Advances in Nursing Science. January, 49-63.

Onah, F.O. (2001). Urban Unemployment Situation in Nigeria. In E.O. Ezeani and N.N. Elekwa (Eds.), Issues in Urbanization and Urban Administration in Nigeria, Enugu: Jamo Enterprises. Pp. 154-167.

Rubin, R.S. (2009). How relevant is the MBA? Assessing the alignment of required curricula and required managerial competencies. Academy of Management Learning \& Education, 8(2), 208-224.

Sailah, Ilah.(2008). Pengembangan Soft Skills di Perguruan Tinggi. Jakarta: Direktorat Jenderal Pendidikan Tinggi.

Salim, Agus. (2006).Teori dan Paradigma Penelitian Sosial. Yogyakarta: Tiara. Wacana.

Santrock, JohnW. (2007).Psikologi Pendidikan.EdisiKedua. Terjemahan.Jakarta:PT Kencana Media Group

SK Mendiknas 045/U/2000 tentang Kurikulum Inti Pendidikan Tinggi.

Smidt, W. (2015). Big Five personality traits as predictors of the academic success of university and college students in early childhood education. Journal of Education for Teaching. 41(4), 385-403.

Sorrell, Jeanne Merkle \& Redmond, Georgine M. (1995). Interviews in qualitative nursing research: differing approaches for ethnographic and phenomenological studies . Journal of Advanced Nursing. 12 (6), June 1995, $1117-1122$.

Spradley, J.P.(1997).Metode Etnografi. Terjemahan oleh Misbah Yulfa Elisabeth.Yogyakarta : PT Tiara Wacana Yogya.

Stagg P .(1996). Initial teacher training and business links: built-in, not bolt-on? Education + Training, 38(4):10-16.

Streubert, H., \& Carpenter, D. (1999). Qualitative Research in Nursing: Advancing the Humanistic Perspective (2nd ed.). Philadelphia, PA: Lippincott Williams \& Wilkins, p. 48.

Sugiyono. (2006).Metode Penelitian Kuantitatif, Kualitatif dan R \&. D.Bandung:Alfabeta

Surjoseputro, Sutarjo. (2014). Passion and Problem Solving Skills. Jurnal Pendidikan Dan Tejada Fernández, J. \& Ruiz Bueno, C. (2016). Evaluación de competencias profesionales en

Educación Superior: Retos e implicaciones. Educación XX1, 19(1), 17-38.

Thongthew, S. (2014). Changes in teacher education in Thailand 1978-2014. Journal of Education for Teaching, 40(5), 543-550.

Utama. A, Rifqiyah N U, Dhenni R, Jajuli A, Nishimura Y, Shimizu H(2009). Detection and Identification of Human Enteroviruses among Healthy Children in Antajaya, Bogor. J. Biotechnology Res in Tropical Region. p. 3.

Van Manen, M. (1990).Researching lived experience: human science for an action sensitive

pedagogy. [Albany, N.Y.], State University of New York Press, p.177.

Widhiarso, Wahyu. (2012). Membaca t-Test. Jogjakarta: Fakultas Psikologi UGM.

Wimpenny \& Gass. (2000).Interviewing in Phenomenology and Grounded Theory. Is there a difference ? Journal of Advanced Nursing 31 (6), 1485-1492.https://ekonomi.kompas.com/read/2017/11/06/153940126/agustus-2017jumlah-pengangguran-naik-menjadi-704-juta-orang. Accessed $5^{\text {th }}$ January 2018.

http://www.biotechindonesia.org/journal/jbr/jbr-2009-01-02/jrb-1-09-2.pdf. Accessed 1 ${ }^{\text {st } J a n u a r i l ~} 2018$.

https://www.ilo.org/ilostat-files/Documents/description_UR_EN.pdf . Accessed 5 ${ }^{\text {th }}$ January 2018.

https://en.wikipedia.org/wiki/Employment . Accessed $7^{\text {th }}$ January 2018. 